\title{
Kolekcja George’a Thomasona (1640-1660). Historia, zawartość i znaczenie
}

Dzieje konfliktu pomiędzy Karolem I a jego poddanymi oraz będące jego konsekwencją wydarzenia: wojna domowa, detronizacja Stuartów, powołanie Republiki i wprowadzenie Protektoratu, stanowią niezwykle popularny temat badań. W efekcie co roku pojawia się przynajmniej kilkadziesiąt nowych publikacji dotyczących tego okresu. Duża ich część, w mniejszym lub większym stopniu, wykorzystuje materiały wchodzącej w skład zbiorów British Library, a wcześniej British Museum, kolekcji George'a Thomasona, znanej również jako Thomason Tracts. Dzięki kolekcjonerskiej pasji jej twórcy historycy dysponują dziś ogromną liczbą często unikalnych źródeł z lat 1641-1660 pozwalających na zajęcie się różnymi aspektami dziejów Wielkiej Brytanii w tym jakże istotnym dla niej okresie.

Od pewnego czasu przedmiotem coraz większego zainteresowania badaczy staje się również sama kolekcja — na przełomie lat osiemdziesiątych i dziewięćdziesiątych XX wieku na łamach czasopisma „Albion” toczyła się dyskusja o Thomason Tracts pomiędzy Stephenem J. Greenbergem a Michealem Mendlem ${ }^{1}$. W roku 1992 David Stoker opublikował w „The Library” artykuł szczegółowo omawiający losy zbiorów

\footnotetext{
1 Por. S. J. Greenberg, Dating Civil War Pamphlets, 1641-1644, „Albion: A Quarterly Journal Concerned with British Studies”, t. 20, nr 3, 1988, s. 387-401; M. Mendle, The Thomason Collection: A Reply to Stephen J. Greenberg, „Albion: A Quarterly Journal Concerned with British Studies”, t. 22, nr 1, 1990, s. 85-93; S. J. Greenberg, The Thomason Collection: Rebuttal to Michael Mendle, „Albion: A Quarterly Journal Concerned with British Studies”, t. 22, nr 1, 1990, s. 95-98.
} 
do momentu, gdy trafily one do British Museum², a latem 2008 roku w Londynie odbyła się, zorganizowana przez University College London i British Library, konferencja Collecting Revolution: The History and Importance of Thomason Tracts ${ }^{3}$. Stała się ona okazją do podsumowania dotychczasowego stanu wiedzy na temat Thomason Tracts, ale także przedstawienia nowych postulatów badawczych, przede wszystkim tych dotyczących pełniejszego wykorzystania poszczególnych typów materiałów z kolekcji Thomasona - rękopisów, książek, druków propagandowych i publikacji prasowych — oraz dalszego rozszerzenia tematyki badań, do których mogłyby być one użyte.

Podobnemu celowi służy również poniższy tekst prezentujący polskiemu czytelnikowi historię, zawartość Thomason Tracts oraz związane z nią możliwości badawcze. Jak dotąd kolekcja Thomasona znana jest bowiem nielicznym polskim uczonym (w zasadzie jedyną próbą wykorzystania na większą skalę zebranych w niej materiałów była praca Jakuba Basisty Propaganda religijna w przededniu i pierwszych latach angielskiej wojny domowej) ${ }^{4}$, a przecież obejmuje również źródła mogące okazać się niezwykle użyteczne w studiach, np. nad stosunkami polsko-angielskimi w latach pięćdziesiątych XVII wieku lub nad działalnością Samuela Hartlieba.

Zanim przejdziemy do omówienia samej kolekcji oraz jej specyfiki, należałoby przybliżyć nieco postać jej twórcy. George Thomason (ok. 1602-1666), choć dziś rozpoznawany jest przede wszystkim jako kolekcjoner, był jednym z bardziej znanych londyńskich wydawców i księgarzy swej epoki ${ }^{5}$. Karierę rozpoczął w roku 1617 jako czeladnik Henry'ego Fetherstone’a, właściciela księgarni The Rose mieszczącej się na dziedzińcu katedry św. Pawła. W czerwcu 1626 roku Thomason został przyjęty do cechu księgarzy (Stationers' Company), a nieco później przejął prowadzenie firmy swego dotychczasowego pracodawcy. W roku

2 Por. D. Stoker, Disposing of George Thomason's Intractable Legacy 1664-1762, „The Library", 6th series, t. 14, 1992, s. 337-357.

3 Szczegółowe informacje o tej konferencji, która odbyła się w dniach 30 VI-1 VII 2008 roku, znajdują się na stronie: http://sites.google.com/site/jtpeacey/ collectingrevolution.

4 Por. J. Basista, Propaganda religijna $w$ przededniu i pierwszych latach angielskiej wojny domowej, Kraków 2007.

5 Por. Oxford Dictionary of National Biography (dalej jako ODNB) sub George Thomason (ok. 1602-1666). Por. też: L. Spencer, The Professional and Literary Connexions of George Thomason, "The Library”, 5th series, t. 13, 1958, s. 102-118; Ead., The Politics of George Thomason, „The Library”, 5th series, t. 14, 1959, s. 11-27. 
1636 Thomason wszedł w spółkę z innym księgarzem — Octavianem Pullenem. Nie wpłynęło to jednak na zwiększenie liczby książek wydawanych przez twórcę interesującej nas kolekcji (w latach 1636-1639 ukazało się jedynie sześć pozycji).

W tym czasie wspólnicy Thomasona (tj. Thomason i Pullen) koncentrowali się bowiem raczej na działalności handlowej, w tym, przede wszystkim, na zapoczątkowanym jeszcze przez Fetherstone'a, imporcie z kontynentu trudno dostępnych w Anglii edycji łacińskich, greckich i hebrajskich (stąd też Thomasona określano niekiedy mianem Latin trader). W związku z tym Thomason wielokrotnie odwiedzał Niemcy (wiadomo, że regularnie bywał na targach we Frankfurcie), Szwajcarię i Niderlandy, a także Włochy (zwłaszcza Wenecję, skąd w 1647 roku sprowadził cenną kolekcję książek hebrajskich i orientalnych, zakupioną następnie przez Parlament dla Uniwersytetu w Cambridge). Innym stałym odbiorcą przywożonych przez niego dzieł była Bodleian Library w Oxfordzie.

W roku 1645, po zakończeniu współpracy z Pullenem, Thomason przeniósł się do nowej księgarni The Rose and Crown, gdzie nadal trudnił się przede wszystkim handlem importowanymi wydawnictwami. W początkach lat czterdziestych zaangażował się także w działania związane z funkcjonowaniem Stationers' Company: zajmował się głównie sprawami finansowymi oraz działalnością polityczną.

Źródła potwierdzają jego dużą aktywność na tym polu: od nadzorowania zbiórki pieniędzy na rzecz armii Parlamentu, poprzez udział w radzie Londynu (skąd w grudniu 1648 roku, po „czystce pułkownika Pride'a”, został usunięty wraz z innymi zwolennikami porozumienia $\mathrm{z}$ monarcha), po zaangażowanie $\mathrm{w}$ próby porozumienia stronnictwa prezbiteriańskiego z przebywającym na wygnaniu Karolem II.

Wiosną 1651 roku Thomason, podobnie jak wielu innych czołowych londyńskich prezbiterian, został aresztowany w związku z tzw. Love Plot i oskarżony o udział w działaniach mających na celu przywrócenie w Anglii monarchii. Mimo poważnych zarzutów (jak wynika z dokumentów śledztwa, Thomason miał przewieść z Bredy do Londynu listy Karola II oraz odgrywać ważną rolę w organizacji spisku) cała sprawa zakończyła się jednak dla niego dość dobrze, gdyż nie poniósł większych konsekwencji, nie licząc tylko kilkutygodniowego pobytu w areszcie i konieczności wpłacenia 1000 funtów kaucji ${ }^{6}$.

6 Por. L. Spencer, The Politics..., s. 19-20. 
Wydarzenia te zniechęciły go jednak do dalszej działalności politycznej i spowodowały, że w kolejnych latach poświęcał się raczej prowadzeniu interesów, życiu rodzinnemu i dalszemu gromadzeniu powstałej jedenaście lat wcześniej kolekcji. Zmarł w lutym lub kwietniu (pojawiają się bowiem pewne niejasności) 1666 roku i został pochowany w Londynie ${ }^{7}$.

O ile dokładna data śmierci Thomasona nie jest nam znana, to posiadamy bardzo precyzyjne informacje na temat tego, kiedy rozpoczął on tworzenie swojej kolekcji. Wspominając o niej w testamencie sporządzonym w 1664 roku, opisał ją jako „Collection of Pamphletts and other writeings and papers bounde up with them of severall volumes gathered by me in the tyme of the late Warren beginning the third day of November A. D. 1640"8. Oczywistym impulsem do działań zmierzających do skompletowania zbioru było zatem rozpoczęcie obrad Długiego Parlamentu, podobnie jak cezurę końcową miała stanowić restauracja Stuartów w maju 1660 roku, choć, jak wynika z zapisków Thomasona, planował on zaniechać działalności kolekcjonerskiej już wiosną 1658 roku. Pod datą 24 marca zanotował bowiem:

This day I did cease my elaborat collection, because the number was so exceedingly few and inconsiderable and not now worth my labour, and the Year 1658 beginning to-morrow I did prefer to put an end to my great paynes and charges. ${ }^{9}$

Jak jednak wynika z ustaleń historyków, wytrwał w swoim postanowieniu około tygodnia, co można chyba tłumaczyć, z jednej strony, swego rodzaju przyzwyczajeniem (o ile nie uzależnieniem) zbieracza, z drugiej natomiast faktem, że na tym etapie Thomason zdawał już sobie najpewniej sprawę z potencjalnego znaczenia swego przedsięwzięcia. Potwierdza to z pewnością kolejny fragment jego testamentu, który podkreślał wyjątkową skalę i unikalny charakter zbioru („soe intire a work and not to be pararelled") ${ }^{10}$.

\footnotetext{
7 Por. $O D N B$.

8 The Will of George Thomason, „The Library”, New series, 1909, s. 34-43.

9 G. K. Fortescue, Catalogue of the Pamphlets, Books, Newspapers, and Manuscripts Relating to the Civil War, the Commonwealth, and Restoration, Collected by George Thomason, 1640-1661, t. 1, London 1908, s. XII.

10 The Will..., s. 39-40.
} 
Rozpoczynając pracę kolekcjonerską, Thomason nie ustalił jasnych kryteriów decydujących o ewentualnym włączeniu danej pozycji do kolekcji i wydaje się, że głównym czynnikiem była po prostu możliwość pozyskania danej publikacji. Biorąc pod uwagę aktywność rynku wydawniczego, dotarcie do wszystkiego, co ukazało się w Anglii w tym okresie, było praktycznie niemożliwe, choć można przyjąć, że — ze względu na swoją profesję, kontakty oraz fakt zamieszkiwania w Londynie - Thomason znajdował się w lepszej, niż inni potencjalni kolekcjonerzy, sytuacji (o czym bardziej szczegółowo za chwilę).

W efekcie w ciągu dwudziestu lat udało mu się zdobyć około 22 tysiące książek, druków propagandowych i polemicznych, newsbooks oraz rękopisów ( $w$ tym również pewne materiały z okresu przed listopadem 1640 roku i z lat 1661-1663), zebranych w ponad 2 tysiące tomów. Według katalogu przygotowanego przez Fortescue w początkach XX wieku, o którym będzie jeszcze mowa, kolekcja obejmuje 14942 książki i broszury, 97 rękopisów oraz 7216 publikacji prasowych ${ }^{11}$.

Nie ma wątpliwości, że Thomason Tracts nigdy nie były, bo i nie mogły być, kompletnym zbiorem wszystkich publikacji wydawanych w Anglii w latach 1640-1660. Dużą, brakującą grupę stanowią choćby publikacje ukazujące się poza Londynem. Oczywistym jest też, że o ostatecznym kształcie kolekcji decydowały także sytuacja na rynku wydawniczym oraz zainteresowania i preferencje samego Thomasona. Mógł on mniej starannie poszukiwać pewnych rodzajów źródeł, równocześnie kładąc nacisk na systematyczne i sumienne pozyskiwanie innych (zauważono np. że w latach pięćdziesiątych w kolekcji pojawiły się praktycznie wszystkie publikacje z tego okresu krytycznie oceniające Cromwella). Trudno jednak doszukiwać się prostego wyjaśnienia istniejących luk. Potwierdzają to choćby obliczenia Joada Raymonda. Przebadał on nabytki Thomasona z roku 1649, z których wynika, że Thomason pominął choćby edycję poezji Johna Donne’a (pozyskał jedynie 2 z 16 almanachów, jakie wyszły w tym roku), ale za to dotarł do prawie wszystkich numerów nielegalnych, rojalistycznych newsbooks takich jak „Mercurius Elencticus” i „Mercurius Pragmaticus”"12.

11 Por. G. K. Fortescue, op. cit., s. XXI.

12 Zagadnienia tego dotyczył niepublikowany referat Joada Raymonda pt. Thomason in 1649, wygłoszony 1 VII 2008 roku podczas konferencji Collecting Revolution... 
Porównanie całości kolekcji Thomasona $\mathrm{z}$ zestawieniami takimi jak przygotowany przez Donalda Winga Short-title catalogue of books printed in England, Scotland, Ireland, Wales, and British America, and of English books printed in other countries, 1641-1700 (STCII $)^{13}$ daje wyobrażenie o tym, jak wiele Thomason zdołał jednak zebrać. Widać, na przykład, że w latach $1641-1650$ było to $59,7 \%$ wszystkich publikacji wykazanych w zestawieniu Winga, z tego $53,1 \%$ publikacji o charakterze nieperiodycznym. W kolejnym dziesięcioleciu (1651-1660) odsetek ten spadł odpowiednio do $43 \%$ i $35,8 \%$. W sumie na przestrzeni dwudziestu lat Thomason pozyskał $53 \%$ wszystkich publikacji, które ukazały się w tym okresie, z tego 45,6\% publikacji o charakterze nieperiodycznym ${ }^{14}$.

Organizacja rosnącej w szybkim tempie kolekcji musiała nastręczać wiele problemów i zapewne dlatego Thomason dość szybko wprowadził system gromadzenia nabywanych materiałów w porządku chronologicznym (według daty pozyskania) i wedle podziału na pięć kategorii określanych przez format (small quatros, large quatros, folios, octavos, acts). Taki układ, choć nie do końca wygodny dla potencjalnych, przyszłych użytkowników kolekcji, pozwalał jednak na dość sprawne porządkowanie napływających stale nowych publikacji.

Te w pewnym stopniu pochodziły z zakupów (Thomason kilkakrotnie podkreślał przy różnych okazjach, że w związku ze swoją działalnością ponosił znaczące wydatki), choć testament księgarza wskazuje, że nie doprowadziły go one z pewnością do ruiny finansowej ${ }^{15}$. Spora część nabytków znalazła się jednak w posiadaniu Thomasona w inny sposób - wiele pozycji, zwłaszcza książkowych, otrzymał w darze od autorów (m.in. Johna Miltona i Samuela Hartliba). Przypuszczalnie pomagały mu też inne osoby wiedzące o istnieniu kolekcji, a związane z rynkiem wydawniczym, w tym księgarze i drukarze (przypomnijmy, że posiadał on liczne kontakty w tych środowiskach). Mogli oni przekazywać pojedyncze egzemplarze, które z różnych powodów nie trafiły do nabywców (tzw. „resztówki”). Sporo jest też w kolekcji materia-

13 Por. Short-title catalogue of books printed in England, Scotland, Ireland, Wales, and British America, and of English books printed in other countries, 1641-1700, New York 1945-1951.

14 Por. J. Raymond, Pamphlets and Pamphleteering in Early Modern Britain, Cambridge 2003, s. 193-195.

15 Por. The Will..., s. 40. 
łów ogólnodostępnych, dystrybuowanych bezpłatnie, przybijanych do drzwi kościołów lub innych budynków, czy nawet „scattered about the streets at night"16.

Mechanizm tworzenia kolekcji możemy poznać przede wszystkim dzięki samemu Thomasonowi, gdyż na kartach tytułowych poszczególnych pozycji notował on różnego rodzaju informacje, takie jak: data akcesji (którą od lata 1642 roku podawał praktycznie zawsze), data publikacji, sposób pozyskania (stąd można łatwo zidentyfikować egzemplarze podarowane przez autorów lub, na przykład, zebrane na ulicy). Adnotacje Thomasona okazują się pomocne także przy rozstrzyganiu wątpliwości co do autorstwa wielu anonimowych druków (wielokrotnie okazywało się bowiem, że rzeczywiście wskazywał on właściwe osoby) oraz ustalenia faktu istnienia więcej niż jednego wydania danej pracy. Zapiski świadczą również o tym, iż Thomason był uważnym czytelnikiem zbieranych przez siebie materiałów (bardzo często komentował ich treść, wskazywał informacje na ten sam temat, które pojawiły się już wcześniej w innym newsbook lub innej pracy, porównywał różne teksty tych samych autorów).

Warto podkreślić, że na systematyczne zdobywanie nowych tekstów nie wpłynęły negatywnie ani wyprawy Thomasona na Kontynent, ani jego aresztowanie w 1651 roku. Wiązało się to zapewne z faktem, że w czasie swoich nieobecności mógł on liczyć na pomoc pracowników, którzy, jak wskazują dane liczbowe, niezwykle sumiennie starali się kontynuować jego działalność. Z jednego z opisów kolekcji, pochodzącego zapewne spod pióra samego Thomasona, dowiadujemy się też, iż na przestrzeni dwudziestu lat trzech z pomagających mu w budowaniu kolekcji współpracowników zmarło, nie doczekawszy chwili, gdy zostanie ona zamknięta ${ }^{17}$.

Liczni współpracownicy, przyjaciele, a później również spadkobiercy Thomasona odegrali również niezwykle ważną rolę w dalszych losach jego zbiorów i przyczynili się do tego, że niemal nietknięte przetrwały liczne niebezpieczeństwa. Pierwsze z nich miało miejsce wiosną 1651 roku, kiedy to, jak pamiętamy, Thomasona aresztowano w związku $\mathrm{z}$ jego domniemanym udziałem $\mathrm{w}$ antyrządowym spisku. Choć nie

16 J. Peacey, Politicians and Pamphleteers. Propaganda During the English Civil Wars and Interregnum, Aldershot 2004, s. 245, przyp. 42.

17 Por. L. Spencer, The Professional..., s. 115. 
ulega wątpliwości, iż przeszukiwano wtedy zarówno jego dom, jak i księgarnię, to władze nie zdołały dotrzeć do zebranych przez niego materiałów. George Fortescue sugerował, jakoby Thomason, na wieść o pierwszych aresztowaniach spiskowców, zdołał wysłać kolekcję do Oxfordu i przekazać ją pod opiekę swego przyjaciela Thomasa Barlowa. Ten, aby zapobiec ewentualnej konfiskacie, miał wystawić fikcyjny dokument potwierdzający jej sprzedaż bibliotece uniwersyteckiej. Kolekcja mogła tam jednak trafić nie tylko ze względów bezpieczeństwa, lecz także dlatego, że już wtedy pojawił się projekt jej ewentualnego zakupu przez Bodleian Library. Potwierdzałby to fakt przesyłania przez Thomasona do Oxfordu kolejnych materiałów. Poza tym, w spisanym w styczniu 1665 roku kodycylu do testamentu informował on o tym, że zbiory nadal znajdują się pod opieką Barlowa oraz o trwających właśnie negocjacjach w sprawie ich sprzedaży (które, jego zdaniem, powinny w niedługim czasie zakończyć się sukcesem). W efekcie Thomason rozporządzał nie tyle samą kolekcją, ile pieniędzmi, jakie miał za nią otrzymać $^{18}$.

Wbrew oczekiwaniom Thomasona rozmowy dotyczące sprzedaży przeciągały się i w efekcie w chwili jego śmierci sprawa dalszych losów zbiorów nie była rozwiązana ${ }^{19}$. Mimo wysiłków ze strony Balowa ostatecznie nie doszło do zakupu przez Bodleian, ponieważ uniwersytetowi nie udało się zgromadzić odpowiednich funduszy (ok. 1200 funtów). Mimo tego kolekcja nadal pozostawała w Oxfordzie. Konieczność znalezienia dla niej nowego miejsca pojawiła się w momencie, gdy Barlow został mianowany biskupem Lincolnu i musiał opuścić uniwersytet. Jak zadeklarował, najchętniej sam zakupiłby materiały, jednak, jak to ujął, „the collection is so grat and my puree soe Little that I Cannot compasse it" ${ }^{\prime 20}$. Równocześnie stwierdzał, że tak cenne źródła trzeba udostępnić czytelnikom, więc najwłaściwszym miejscem ich przechowywania powinna być otwarta dla publiczności biblioteka.

Jego sugestia została przynajmniej w teorii zrealizowana wtedy, gdy kolekcja pod koniec lat siedemdziesiątych została sprzedana przez spadkobierców Thomasona królewskiemu introligatorowi Samuelowi Marnemu. Wszystko wskazuje bowiem na to, że działał on jedynie jako

18 Por. D. Stoker, Disposing of..., s. 339.

19 Por. ibidem, s. 337 i n.

20 Ibidem, s. 339. 
agent Karola II, a zbiory miały trafić do Royal Library w Whitehall. Ponieważ jednak monarcha zwlekał ze zwrotem wyłożonych przez Marne'a środków, ten zatrzymał je (dodatkowo przywłaszczył sobie również kilkadziesiąt cennych książek hebrajskich, przekazanych mu z biblioteki królewskiej do oprawy), a następnie przekazał swoim spadkobiercom, którzy przez wiele lat próbowali odzyskać zamrożony w nich kapitał. Mimo przygotowania swego rodzaju „prospektu reklamowego" (A Complete Collections of Books and Pamphlets Biegun in the Year 1640), do sprzedaży jednak nie doszło, a kolekcja drogą dziedziczenia przeszła w ręce rodziny Sisson, nadal bezskutecznie starającej się znaleźć chętnych do jej kupna.

W roku 1707 ponownie pojawiła się perspektywa nabycia materiałów Thomasona przez Bodleian Library (za sumę 735 funtów), jednak, tak jak i za pierwszym razem, negocjacje zaczęły się przeciągać. Sprawa rozbijała się tradycyjnie o brak funduszy i kłopoty decyzyjne na uniwersytecie, jednak dodatkowo komplikowały ją nie do końca jasne roszczenia do kolekcji zgłaszane przez nieznane bliżej osoby. Właściciele prowadzili równocześnie rozmowy z innymi potencjalnymi kupującymi, ale także bez większych sukcesów.

Kolejne próby wystawienia zbiorów na sprzedaż podjęto dopiero w latach pięćdziesiątych XVIII stulecia. Ponownie zaoferowano je Oxfordowi, ale zdecydowano się również poszukać innych ewentualnych nabywców. W roku 1754 aktualna właścicielka, Elizabeth Sisson, przesłała jeden z egzemplarzy spisanego przez Thomasona katalogu znanemu antykwariuszowi i wydawcy — Thomasowi Birchowi, aby ten mógł ocenić zawartość kolekcji. Birch był w tym czasie jednym z kuratorów nowo powstałego British Museum i najprawdopodobniej to właśnie on mógł jako pierwszy zasugerować, że zbiory Thomasona byłyby dla tej instytucji cennym nabytkiem. Trafily one tam jednak dopiero w 1762 roku i to dość okrężną drogą, ponieważ zostały zakupione przez sekretarza stanu Johna Stuarta, trzeciego hrabiego Bute, a następnie przekazane jako dar dla muzeum w imieniu Jerzego III, który zwrócił swojemu ministrowi koszty zakupy, czyli 300 funtów. Zgodnie z decyzją kuratorów muzeum, Thomason Tracts dołączono do tzw. Royal Library kolekcji przekazanej w 1757 roku przez Jerzego II (w jej ramach zbiory funkcjonowały przez kolejne dwa stulecia) ${ }^{21}$. W końcu w roku 1973

21 Por. ibidem, s. 353. 
kolekcja George’a Thomasona trafiła do British Library, gdzie znajduje się obecnie.

Problemy ze sprzedażą oraz skomplikowane losy kolekcji przyczyniły się jednak — paradoksalnie — do zachowania jej w praktycznie nienaruszonym stanie. Przeciągające się negocjacje z Bodleian spowodowały, że zbiory Thomasona znajdowały się w Oxfordzie we wrześniu 1666 roku, gdy wielki pożar Londynu zniszczył całkowicie dużą część City, w tym „zagłębie” księgarskie w okolicach katedry św. Pawła, natomiast fakt, że Samuel Marne zatrzymał ją jako zabezpieczenie należnych mu wypłat, zapobiegł jej zniszczeniu w pożarze Whitehall w 1698 roku, gdzie miała trafić jako część królewskiej biblioteki. Również to, iż dla kolejnych właścicieli stanowiła ona kłopotliwy, bo zamrożony, ale jednak spory kapitał, zmuszało do starań, aby zachować ją w jak najlepszym stanie. Trzeba też pamiętać, że właściciele kolekcji, często zawodowo związani z rynkiem księgarskim, bez trudu mogli dokonać fachowej oceny i w razie potrzeby zlecić lub samodzielnie przeprowadzić konieczną konserwację. W efekcie, jak wynika z obliczeń Fortescue, do momentu, gdy zbiory umieszczono w British Museum, zaginęło lub uległo zniszczeniu jedynie 29 tomów, zawierających 145 pozycji, czyli mniej niż $1 \%$ całości.

Przejęcie gromadzonych przez Thomasona materiałów przez British Museum spowodowało, że kolekcję udostępniono w końcu czytelnikom, a to pociągnęło za sobą konieczność jej nowego skatalogowania. Sam Thomason prowadził nie tyle katalog swoich zbiorów, ile raczej księgę akcesji. Ostatecznie złożyło się na nią 12 tomów (rękopis, dwa komplety) odzwierciedlających układ, w jakim pierwotnie przechowywano materiały, tj. w porządku chronologicznym i według formatu. W początkach XX wieku zostały one jednak, jak już wspomniano, na nowo skatalogowane przez Geoerge'a Fortescue, kustosza zbiorów bibliotecznych British Museum, co wiązało się z pewnymi zmianami układu katalogu.

Zmiany systemu katalogowania oraz wprowadzenie nowych sygnatur (bardzo łatwo rozpoznawalnych dzięki charakterystycznemu „E” na początku) po 1762 roku wzbudzają wiele kontrowersji wśród badaczy zajmujących się historią kolekcji. Ich uwagi skupiają się zazwyczaj na wpływie innowacji na możliwości wykorzystania Thomason Tracts, a przez to - na wartość części materiałów. Przykładem tego typu dysku- 
sji może być, wspomniana na wstępie, polemika pomiędzy Stephanem J. Greenbergiem i Michaelem Mendlem. Zdaniem pierwszego, zmiany układu materiałów, jakie narzucał nowy system, utrudniają potencjalnym czytelnikom odszukanie części z nich oraz powodują, że przygotowany przez Fortescue katalog nie obejmuje całości zbiorów. Mendle z kolei ocenia, że modyfikacje te nie były tak drastyczne, a sięganie raczej do rękopiśmiennych opisów zawartości kolekcji pozostawionych przez Thomasona niż do katalogu Fortescue, mimo jego niedociągnięć, nie rozwiązuje problemu, a nawet może go powiększyćc ${ }^{22}$.

O podobnych komplikacjach związanych z korzystaniem $\mathrm{z}$ Thomason Tracts wspominają także historycy literatury (dla nich również zbiory mogą stanowić niezwykle cenną bazę źródłowa). John T. Shawcross w tekście dotyczącym znaczenia kolekcji Thomasona dla badań nad twórczością Johna Miltona wykazał, że dokładniejsza analiza kolekcji (w tym uwzględnienie materiałów, dotarcie do których utrudniają problemy z korzystaniem z katalogu Fortescue) może przyczynić się znacząco do wzbogacenia interpretacji dzieł Miltona oraz ich dokładniejszego datowania ${ }^{23}$. Shawcross za pomocne uznał zarówno zgromadzone przez Thomasona edycje prac Miltona, ale również teksty polemiczne pozwalające na odtworzenie poglądów innych uczestników debaty politycznej i religijnej, w którą wpisywały się liczne publikacje poety.

Thomason Tracts mają też ogromne znaczenie dla historyków prasy. Analiza zawartości zbioru wskazuje jednoznacznie, że efektywność Thomasona jako kolekcjonera ulegała dość istotnym zmianom, natomiast niezależnie od jej spadku lub wzrostu był on bardziej „skuteczny” w pozyskiwaniu newsbooks, czyli prasy informacyjnej, niż innego typu wydawnictw ${ }^{24}$. W efekcie, pod względem bogactwa tego typu publikacji ze zbiorami Thomasona nie mogą się równać ani zasoby Folger Shakespeare Library czy Worcester College w Oxfordzie, obejmujących, jak wiadomo, wyjątkowo cenne zbiory publikacji prasowych z tego okre$\mathrm{su}^{25}$. Przypadki, w których tytuł prasowy nie jest obecny w kolekcji

22 Por. S. J. Greenberg, Dating Civil War Pamphlets..., s. 387-401; M. Mendle, op. cit., s. 85-93; S. J. Greenberg, The Thomason Collection..., s. 95-98.

23 Por. J. T. Shawcross, Using the Thomason Tracts and Their Significance for Milton Studies, „SEL Studies in English Literature 1500-1900”, t. 49, nr 1, 2009, s. 145-172.

24 Por. J. Raymond, Pamphlets and..., s. 193.

25 Na temat zbiorów prasy w Fogler Library por. C. R. Kyle, J. Peacey, Breaking News, Reneissance Journalism and the Birth of the Newspaper, Washington D. C. 2008. 
Thomasona, a zachował się w którejś z wymienionych kolekcji, oczywiście się zdarzają, ale niezbyt często ${ }^{26}$. Podobnie ma się rzecz z dwoma pozostałymi, największymi kolekcjami wczesnej prasy angielskiej: Burney Collection (z British Library) i Nichols Collection (stanowiącą część zbiorów Bodleian Library). Ich podstawę ukształtowała kolekcja Narcissusa Luttrella (pierwotnie obejmująca głównie materiały z lat osiemdziesiątych i dziewięćdziesiątych XVII wieku), ale obecnie dominują w nich przede wszystkim źródła osiemnastowieczne. W Burney i Nichols Collection znajdują się, co prawda, również pozycje pochodzące z okresu przed 1660 rokiem, ale stanowią one jedynie niewielką ich część, która w większości pokrywa się ze zbiorami Thomasona ${ }^{27}$.

Z ogólnej oceny zebranych przez Thomasona newsbooks wynika, że na pozyskiwanie tego typu publikacji kładł on szczególny nacisk. Można zaryzykować nawet tezę, że to pojawienie się pierwszych takich wydawnictw w listopadzie i grudniu 1641 roku skłoniło go do zintensyfikowania działań kolekcjonerskich ${ }^{28}$. Z całą pewnością dotarcie do nich ułatwiał mu fakt, że w zdecydowanej większości ukazywały się one w Londynie i w określonych dniach tygodnia, co pozwalało na ich regularne nabywanie.

Najdobitniej szczególne zainteresowanie Thomasona newsbooks potwierdzają jednak dane liczbowe. Przeprowadzone przez Joada Raymonda porównanie z STCII pokazuje, iż w latach 1641-1650 Thomason zdołał dotrzeć do $80,9 \%$ wszystkich newsbooks, jakie się ukazały.

O zbiorach Worcester College por. P. Morgan, Oxford libraries outside the Bodleian, Oxford 1980, s. 151-154.

26 W Thomason Tracts brakuje np. „Nouvelles ordinaires de Londre” (1650-1661), wydawanych przez Nicolasa Bourneta. Jedyny zachowany komplet znajduje się w zbiorach biblioteki Uniwersytetu Yale.

27 Wyobrażenie o bogactwie zbiorów Thomasona daje porównanie zasobu Burney Collection i Thomason Tracts. W przypadku newsbooks z czasów Protektoratu (XII 1653-V 1659) na 40 tytułów wymienionych w przez Nelson i Seccombe'ego (por. C. Nelson, M. Seccombe, British Newspapers and Periodicals, 1641-1700. Short-title Catalogue, New York 1987, dalej: N\&S) w Thomason Tracts nie pojawia się jedynie 6, gdy tymczasem w Burney Collection liczba ta wynosi 23. Poza tym, często zdarzają się sytuacje, gdy w Thomason Tracts zachował się komplet lub niemal komplet wydań danego tytułu, a w Burney Collection — jedynie jego pojedyncze egzemplarze. Por. choćby N\&S, nr 150, 496.

28 Por. J. Raymond, The Invention of the Newspaper. English Newsbooks 1641-1649, Oxford 2005, s. 13. 
W czasie od 1651 do 1660 roku odsetek ten wyniósł 68\%, co w sumie daje 76,3\% wszystkich publikacji tego typu z okresu 1641-166029.

Przechodząc do konkretnych danych liczbowych: w Thomason Tracts zachowało się do dziś 396 tytułów newsbooks, które w sumie obejmują nieco ponad 7200 numerów. Oczywiście są one różnorodne: od wydawnictw efemerycznych, kończących swój żywot po ukazaniu się jednego lub dwóch numerów, po publikacje takie jak „Mercurius Politicus" (ukazywał się od czerwca 1650 do kwietnia 1660 roku i osiaggnął liczbę 515 numerów). Poza tym, w kolekcji znajdziemy zarówno tytuły stosunkowo niezależne, nielegalne, od pewnego momentu publikacje rojalistyczne, jak i pozycje koncesjonowane przez władze Republiki. Co warte podkreślenia, nawet w okresie, gdy wiosną 1658 roku Thomason próbował ograniczyć swoją aktywność kolekcjonerską, nadal nabywał newsbooks, a w kolekcji znajdują się wszystkie numery z marca i początków kwietnia 1658 roku $^{30}$.

Podsumowując, nie ulega wątpliwości, że tak bogaty zbiór jak Thomason Tracts daje rzeczywiście niezwykle szerokie możliwości badawcze. Oczywiście, zebrane materiały służą przede wszystkim jako baza źródłowa do badań nad dziejami wewnętrznymi Wielkiej Brytanii, począwszy od kwestii czysto politycznych poprzez religijne, społeczne po historię kultury i literatury ${ }^{31}$. Nie można jednak zapominać, że Thomason Tracts mogą być też traktowane jako świadectwo dramatycznych przeobrażeń, jakie pojawiły się w życiu politycznym i kulturalnym tego kraju, ale również w życiu jego zwykłych obywateli wraz ze zwołaniem Długiego Parlamentu, wybuchem otwartego konfliktu pomiędzy królem i jego — najpierw szkockimi, a później i angielskimi — poddanymi. Trudno bowiem wyobrazić sobie, by w innych okolicznościach Thomason zdecydował się na podjęcie i kontynuację przez całe dwa dziesięciolecia swego, prowadzonego przecież na tak ogromną skalę, dzieła.

\footnotetext{
29 Por. J. Raymond, Pamphlets and..., s. 193.

30 Por. N\&S, s. 236, 239-240.

31 Materiały mogą jednak oczywiście same stać się przedmiotem badań, w tym także tych charakteryzujących się niekiedy dość niekonwencjonalną metodologią. Za ilustrację może posłużyć tu próba statystycznej analizy zebranych przez Thomasona źródeł (publikacji nieperiodycznych) z wykorzystaniem narzędzi oferowanych przez nowoczesne technologie komputerowe (por. T. N. Corns, Publication and Politics, 1640-1661: A SPSS-based Account of the Thomason Collection of Civil War Tracts, „Literary and Linguistic Computing”, t. 1, nr 2, s. 74-84).
} 


\section{The Collection of George Thomason (1640-1660). History, Contents and Importance}

The text presents the history and research possibilities provided by a unique collection of books, prints, newspapers and manuscripts gathered by the 17th-century London bookseller George Thomason. Known also as the Thomason Tracts, the collection, containing over 20000 items, is one of the most important assemblies of primary sources from the period of the Civil War and Interregnum and has been extensively used by historians. The article also argues that due to Thomason's diligence in collecting early periodical publications and the fact that the Thomason Tracts have been preserved almost intact they are of key importance for anyone planning to conduct research on the history of early English newspapers and journalism. 